Article

\title{
Design and Thermodynamic Analysis of Waste Heat-Driven Zeolite-Water Continuous-Adsorption Refrigeration and Heat Pump System for Ships
}

\author{
Cüneyt Ezgi (1)
}

check for

updates

Citation: Ezgi, C. Design and Thermodynamic Analysis of Waste Heat-Driven Zeolite-Water Continuous-Adsorption Refrigeration and Heat Pump System for Ships. Energies 2021, 14, 699. https:// doi.org/10.3390/en14030699

Academic Editors: Ciro Aprea, Angelo Maiorino and Adrián Mota Babiloni

Received: 22 December 2020

Accepted: 26 January 2021

Published: 29 January 2021

Publisher's Note: MDPI stays neutral with regard to jurisdictional claims in published maps and institutional affiliations.

Copyright: (C) 2021 by the author. Licensee MDPI, Basel, Switzerland. This article is an open access article distributed under the terms and conditions of the Creative Commons Attribution (CC BY) license (https:// creativecommons.org/licenses/by/ $4.0 /)$.
Department of Marine Engineering, Piri Reis University, 34940 Istanbul, Turkey; cezgi@pirireis.edu.tr; Tel.: +90-216-581-0051

\begin{abstract}
Strict International Maritime Organization (IMO) rules enable ships to maximize fuel consumption and compliance with the climate. Cooling and heat-pumping technology powered by waste heat makes a substantial contribution to lowering ship gas emissions. This study explores, technically studies, and thermodynamically analyzes the efficiency of ongoing adsorption refrigeration and heating systems using a zeolite-water pair onboard a naval surface ship. An updated Dubin-in-Astakhov equation calculates the equilibrium adsorption potential of the operating pair used in the system. The coefficient of performance (COP) and specific cooling power (SCP)/specific heating power (SHP) values were between 0.109 and 0.384 and between 69.13 and $193.58 \mathrm{~W} \mathrm{~kg}^{-1}$ for cooling mode, and between 66.16 and $185.26 \mathrm{~W} \mathrm{~kg}^{-1}$ based on exhaust gas temperature and regeneration, respectively. Up to $27.64 \%$ and $52.91 \%$ met the cooling and heating load of the case vessel at a full load by the zeolite-water-adsorbed refrigeration/heat-pumping system. The COP of the heat pump and cooling systems was compared to that of adsorption cooling/heat pumps in the literature.
\end{abstract}

Keywords: zeolite; water; adsorption; refrigeration; heat pump; ship

\section{Introduction}

A new International Convention for the Prevention of Pollution from Ships (MARPOL) Annex VI Chapter 4 titled "regulations on energy efficiency for ships" (2011) was adopted by the International Maritime Organization (IMO) to monitor greenhouse-gas emissions (GHGs) in vessels, with the energy design index (EEDI) and ship performance schedule as the indicators (SEEMP). IMO initiatives are expected to have a substantial effect on the climate and human wellbeing.

The compressor is the origin of the cooling and heat pump system vapor compressor. Traditional system compressors are usually powered by electricity and require a high degree of cooling and heating capacity per $\mathrm{kW}$. Increasing fuel prices and the enforcement of MARPOL contribute to more fuel-efficient options for those choices.

Ezgi [1] tested, studied, and developed a steam ejector for naval surface ship applications, such as a LiBr-water absorption heat pump system [2]. In a laboratory heat-driven diesel engine, Ezgi et al. [3] conducted experimental analysis on absorption cooling with ammonia-water. The two internal-combustion (IC) engines onboard vessels were tested by Shu et al. [4], who found that their poor output coefficient was the biggest challenge in the advancement of adsorption-refrigeration technology.

$\mathrm{Xu}$ et al. [5] studied cooling systems for engine exhaust heat fishing boats. Adsorption, absorption, and exhaust cooling systems used in fishing vessels were compared. Qi et al. [6] introduced a new exhaust-driven ice maker on a fishing boat.

Several cooling technologies were developed in fishery boats by Wang et al. [7]. Li et al. [8] studied adsorption cooling development in modern beds and advanced cycles. Demir et al. [9] studied an adsorption heat pump and compared it with vapor compression 
refrigeration. Wang et al. [10] studied several adsorbents, such as physical, chemical, and composite. Wang et al. [11] created an activated carbon-methanol adsorption cooling system for a fishing boat. Wang et al. [12] proposed prototypes for the use of waste heat or solar energy as the main heat source, as waste heat can be produced by diesel motors or power plants, and the testing of silica gel-water chillers can be fed with hot water colder than $55^{\circ} \mathrm{C}$. Wang et al. [13] investigated cooling-adsorption strategies and the adsorption loss of physical adsorption equipment. A $13 \mathrm{X}$ zeolite-water working couple, which is used to condition the air in trucks engineered with an engine waste-heating system, was introduced by Wu et al. [14] in a modified adsorption cooling unit.

The novelty of this research article is that the condenser temperature is high in the system, at $50{ }^{\circ} \mathrm{C}$, due to the heat pump as well as the analysis of a dual-purpose zeolitewater adsorption refrigeration and heat pump system on ships. There is no research in the literature on the refrigeration and heat pump method of zeolite-water for naval ship applications. This study studied and designed a cooling and heat pump heat recovery method of adsorption onboard ships to boost the fuel economy and compatibility with the climate.

\section{Refrigeration and Heat Pump System Selection and Design}

Traditionally, refrigeration on ships is provided by seawater-cooled chiller units, while electric duct heaters, hot water, or steam boilers/generators are used depending on the heating requirements of various compartments.

Waste heat-driven refrigeration and heat pump systems for ships are the best choice to help protect the environment and save fuel. To follow MARPOL regulations, waste heat-driven refrigeration and heat pump systems have to be selected. These devices can significantly save electricity, have low carbon emissions, and carry less risk of ozone depletion. Continual cooling-adsorption and heat pump systems are a type of waste heat-driven system.

We considered the effectiveness, protection, durability, easy implementation, and safety of the atmosphere in selecting adsorption pairs. Usual pairs are activated carbon-methanol, active carbon-ammonia, silica gel-water, and zeolite-water for physical adsorption.

Water, except for its very low saturation, can be considered as a perfect coolant. Silica gel is commonly used in pairs of liquids. The desorption temperature is very low, exceeding $50{ }^{\circ} \mathrm{C}$, but not $120^{\circ} \mathrm{C}$. Water is typically used in a silica gel or zeolite pair. Silica gel is destroyed above $120^{\circ} \mathrm{C}$ [15].

The pair of zeolite-water can be used in heat pump and refrigeration adsorption systems. Zeolite is an aluminum alkaline or alkaline rock crystal. The heat of the zeolitewater pair is greater than that of the silica gel-water pair. Zeolite-water is stable at high temperatures and does not break down at high-temperature pressure like silica gel [15].

The coefficient of performance (COP) and specific cooling power (SCP) of the zeolitewater pair are greater than those of the carbon and methanol active pair, while the temperature of the heat source is above $200{ }^{\circ} \mathrm{C}$ [15].

Just $25-50 \%$ of the overall fuel combustion capacity of the main diesel engine is supplied. Shu et al. [4] used a heat-equilibrium diagram for a shaft power output of $49.3 \%$. They demonstrated that excess energy comprises $2.9 \%$ lubricant oil cooling, $5.2 \%$ jacket water cooling, $25.5 \%$ exhaust gas, $16.5 \%$ air cooling, and $0.6 \%$ heat radiation. Ouadha et al. [16] studied the viability of operating an ammonia-water absorbing-refrigeration device with waste heat from marine diesel engines and demonstrated performance of $48.5 \%$ on a marine diesel engine.

The surplus heat of gas emissions is between $25 \%$ and $30 \%$ of combustion heat. The motor is in the range of $400-550{ }^{\circ} \mathrm{C}$ at exhaust temperature. The dew point of exhaust gas does not drop below $180^{\circ} \mathrm{C}$ owing to the degradation of acid oxide. Therefore, heat-driven main engine exhaust technology is preferable for heating and refreshing ship spaces.

A two-stroke diesel engine's cooling water jacket temperature $\left(60\right.$ to $\left.70^{\circ} \mathrm{C}\right)$ may not reach the necessary silica gel-water pair power specifications in a bed pump device $\left(50^{\circ} \mathrm{C}\right)$, 
and silica gel exhaust heat $\left(>120^{\circ} \mathrm{C}\right)$ is lost. Consequently, silica gel-water was not used in this work.

Zeolite-water is a working adsorption pair, so it is more stable at high temperatures and stronger than ammonia and silica gel-water because of its adsorption thermal content. The continuous zeolite-water adsorption refrigeration and heat pump system are to cool and heat ship spaces, respectively. Waste heat is a diesel engine's waste heat. According to Loydu, at the entry of a naval vessel, the seawater temperature [17] should be -2 to $32{ }^{\circ} \mathrm{C}$ for heating/cooling systems. Design specifications are given in Table 1.

Table 1. Design conditions.

\begin{tabular}{cc}
\hline Waste Heat-Driven Technology & $\begin{array}{c}\text { Continuous-Adsorption Refrigeration and } \\
\text { Heat Pump }\end{array}$ \\
\hline Bed number & Two adsorbent beds \\
Type of working pairs & Zeolite-water \\
Energy source & Diesel engine exhaust heat \\
Seawater temperature & $-2{ }^{\circ} \mathrm{C}$ to $+32^{\circ} \mathrm{C}$ \\
Chilled water outlet-inlet temperatures & $7-12{ }^{\circ} \mathrm{C}$ \\
Hot water outlet-inlet temperatures & $45-40{ }^{\circ} \mathrm{C}$ \\
\hline
\end{tabular}

The main engines in a naval ship are two-stroke diesel engines (1600 BHP and 350-750 rpm). A high outlet temperature of $410{ }^{\circ} \mathrm{C}$ for the exhaust gas is from the diesel motor of the ship. The case ship has a 70 and $35 \mathrm{~kW}$ of refrigeration and heating load, respectively. For the cooling load, a marine vapor-compression refrigeration system is used, and electric heaters are fitted for the heating load.

The schemes in Figure 1 demonstrate the continuous adsorption cooling and heat pump system. Allowing for continuous refolding and heat output, two beds work alternately. A condenser, throttle valve, and evaporator are used in the system. There are two adsorbent beds. The condenser and evaporator are a seawater-cooled shell and tube heat exchanger, respectively.

The system is driven by the exhaust waste of a diesel engine. The full cycle consists of four stages: heating the bed, desorption and regeneration, cooling, and adsorption. During the heating stage, the bed is heated with exhaust heat coming from the main engine, resulting in increased pressure and temperature. After reaching the condensing pressure, the desorption process starts. The bed is completely regenerated at this stage. The water that leaves the bed is condensed, rejecting its heat in the condenser. In the next step, the adsorber is cooled, which results in a decrease in temperature and pressure. When the pressure drops to the evaporation pressure, the adsorption process begins and heat is rejected to seawater. The liquid water at the exit of the condenser is throttled to the evaporator pressure by passing it through a throttle valve and the cycle is completed.

The cooling effect happens during the isobaric adsorption when the heat from chilled water evaporates the adsorbate. The heating effect emerges at the isobaric desorption stage when the adsorbate is condensed by releasing heat to water in condenser. The adsorbent bed is cooled at isobaric adsorption and isosteric cooling stage and the heat released is rejected to seawater.

Seawater (S) circulates the evaporator (E) during the heating mode, and the condenser (C) during the cooling mode. The hot or cold water, via two 4-way, 3-position (4/3) valves, condenser-evaporator-fan coil-seawater (also called CEFS), enters the fan coils (F) of the ship. 


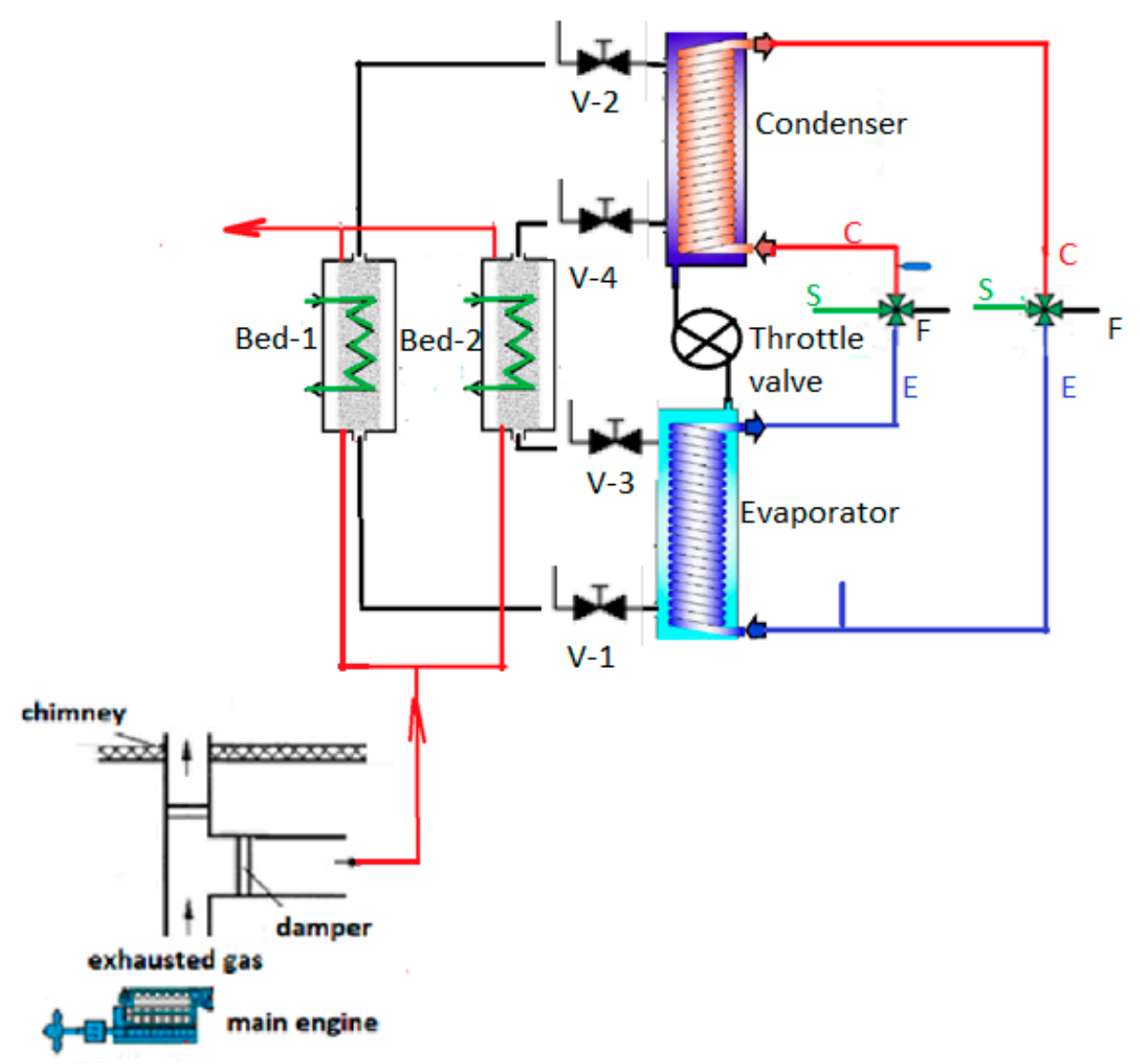

Figure 1. Onboard naval vessel cooling-adsorption and heat pump system.

In this study, the two-bed design was used because it is straightforward compared with a multibed system. The machine's adsorbing bed takes around $30 \mathrm{~min}$ of cooling and 60 min of heating time.

Adsorbent bed 1 was adjusted at a time of 0 to desorption. Then, adsorption bed 2 was heated on $t$, and adsorbing bed 1 was switched onto the adsorbing bed. A loop ended when there was a cycle time of $2 t$. The next cycle was 2 to $4 t$ for the two-bed configuration under standard operating conditions. The controller controlled four solenoid valves V1-V4. The valve function of the two beds is shown in Table 2.

As adsorbers have several industrial uses and low energy consumption, finned tube heat exchangers [18] are used as adsorbers. An increase of seawater temperature of $5{ }^{\circ} \mathrm{C}$ is considered. There was $100 \mathrm{~kg}$ of zeolites per adsorber. Table 3 lists the substance features used in the adsorbent bed. The basic heat of zeolite and water for the potential full load was determined using data given in [9].

Table 2. Two-bed operation in the adsorption system $(\mathrm{X}=$ closed, $\mathrm{O}=$ open).

\begin{tabular}{lllllll}
\hline \multicolumn{1}{c}{ Mode } & Bed 1 & Bed 2 & V1 & V2 & V3 & V4 \\
\hline Mode A-Switching & Heating & Cooling & X & X & X & X \\
Mode B-Adsorber/Desorber & Heating & Cooling & O & X & O & X \\
Mode C-Switching & Cooling & Heating & X & X & X & X \\
Mode D-Adsorber/Desorber & Cooling & Heating & X & O & $X$ & O \\
\hline
\end{tabular}


Table 3. Properties of materials used in the adsorbent bed.

\begin{tabular}{cc}
\hline Zeolite mass $(\mathrm{kg})$ & 100 \\
Metal mass of adsorbent bed $(\mathrm{kg})$ & 100 \\
Average adsorption heat $\left(\mathrm{kJ} \mathrm{kg}^{-1}\right)$ & $4400[9]$ \\
Specific heat of zeolite $\left(\mathrm{kJ} \mathrm{kg}^{-1} \mathrm{~K}^{-1}\right)$ & $0.92[9]$ \\
Specific heat of water $\left(\mathrm{kJ} \mathrm{kg}^{-1} \mathrm{~K}^{-1}\right)$ & 4.18 \\
Specific heat of stainless steel (AISI 316; kJ kg-1 $\left.\mathrm{K}^{-1}\right)$ & 0.468 \\
\hline
\end{tabular}

\section{Thermodynamic Analysis of Adsorption Refrigeration and Heat Pump System}

The diagram of the operating pair for physical adsorption in Clapeyron is shown in Figure 2 [15], with isosteric heating (1-2), isobaric desorption (2-3), isosteric cooling (3-4), and isobaric adsorption (4-1). Figure 3 displays the pressure-temperature (P-T) diagram of physical adsorption.

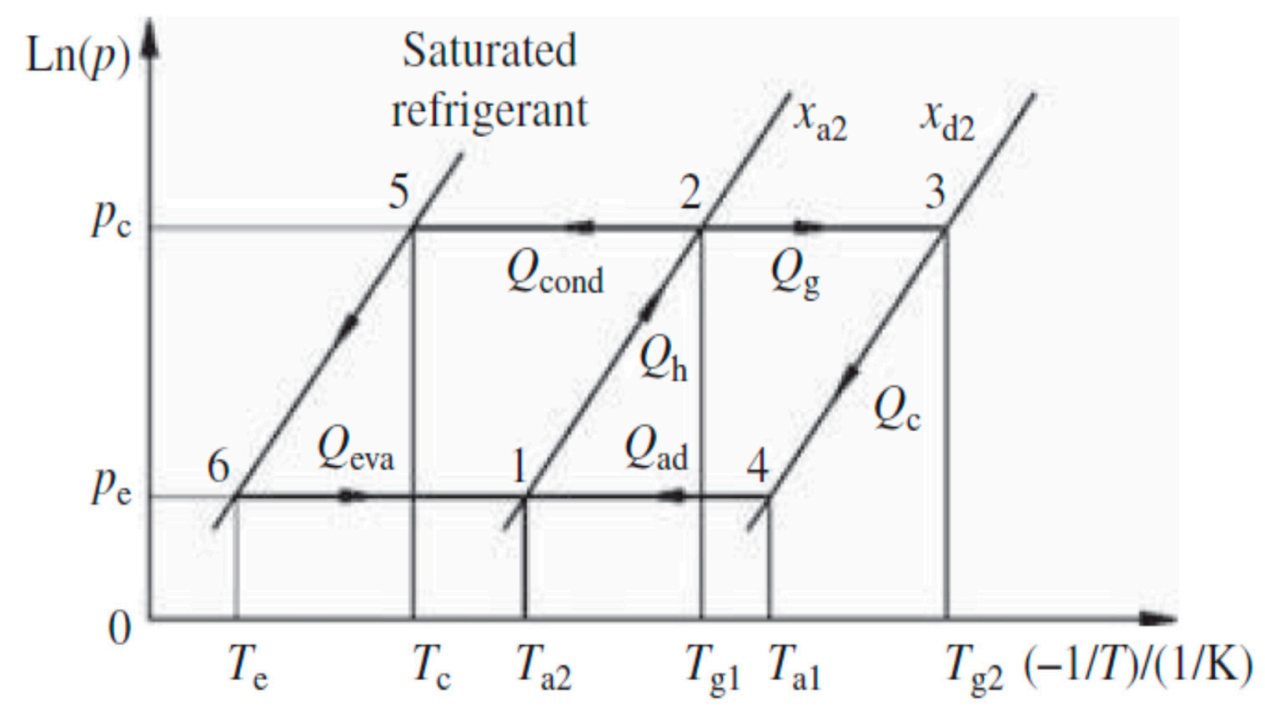

Figure 2. Physical-adsorption map.

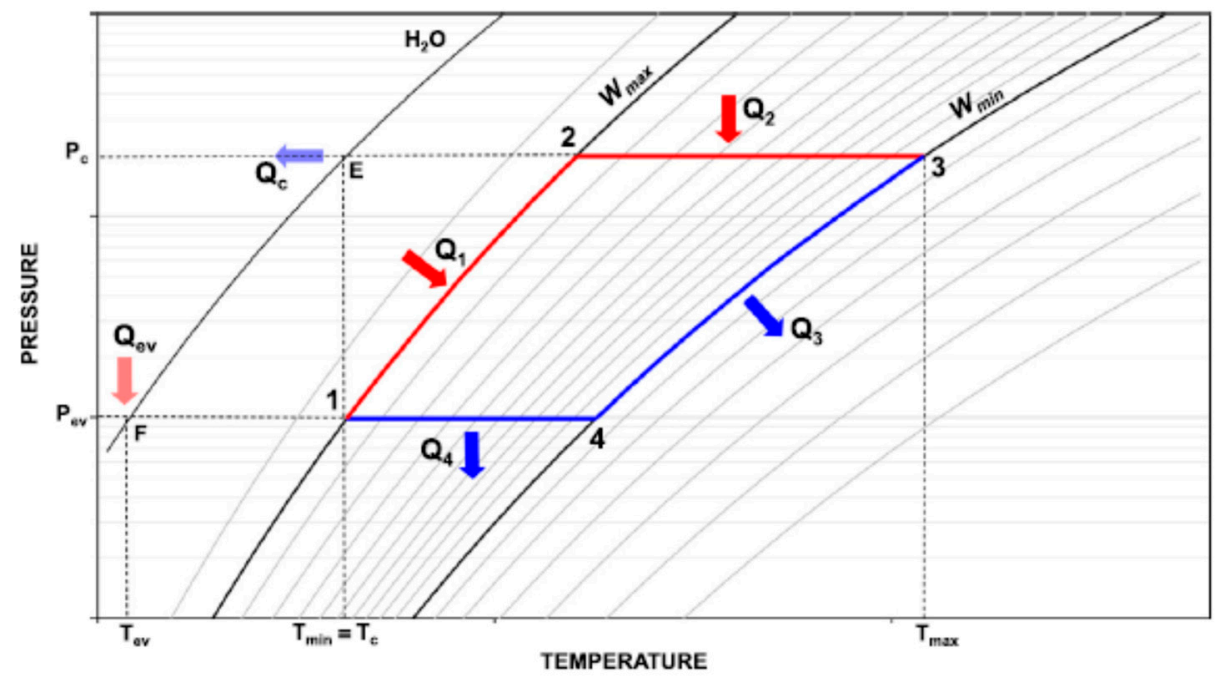

Figure 3. Pressure-temperature $(\mathrm{P}-\mathrm{T})$ diagram of physical adsorption.

Governing equations for the physical adsorption cooling and heat pump mechanism are as follows [15]. 
Sensible heat between 1 and 2 is

$$
\mathrm{Q}_{\mathrm{h}}=\int_{\mathrm{T}_{\mathrm{a} 2}}^{\mathrm{T}_{\mathrm{g} 1}} \mathrm{C}_{\mathrm{a}}(\mathrm{T}) \mathrm{M}_{\mathrm{a}} \mathrm{dT}+\int_{\mathrm{T}_{\mathrm{a} 2}}^{\mathrm{T}_{\mathrm{g} 1}} \mathrm{C}_{\mathrm{Lc}}(\mathrm{T}) \mathrm{M}_{\mathrm{a}} \mathrm{X}_{\mathrm{a} 2} \mathrm{dT}+\int_{\mathrm{T}_{\mathrm{a} 2}}^{\mathrm{T}_{\mathrm{g} 1}} \mathrm{C}_{\mathrm{m}}(\mathrm{T}) \mathrm{M}_{\text {madb }} \mathrm{dT} .
$$

Desorption heat between 2 and 3 is

$$
\mathrm{Q}_{\mathrm{d}}=\int_{\mathrm{T}_{\mathrm{g} 1}}^{\mathrm{T}_{\mathrm{g} 2}} \mathrm{C}_{\mathrm{a}}(\mathrm{T}) \mathrm{M}_{\mathrm{a}} \mathrm{dT}+\int_{\mathrm{T}_{\mathrm{g} 1}}^{\mathrm{T}_{\mathrm{g} 2}} \mathrm{C}_{\mathrm{Lc}}(\mathrm{T}) \mathrm{M}_{\mathrm{a}} \mathrm{XdT}+\int_{\mathrm{T}_{\mathrm{g} 1}}^{\mathrm{T}_{\mathrm{g} 2}} \mathrm{C}_{\mathrm{m}}(\mathrm{T}) \mathrm{M}_{\mathrm{madb}} \mathrm{dT}-\int_{\mathrm{T}_{\mathrm{g} 1}}^{\mathrm{T}_{\mathrm{g} 2}} \mathrm{M}_{\mathrm{a}} \mathrm{h}_{\mathrm{d}} \frac{\mathrm{d} x}{\mathrm{dT}} \mathrm{dT} .
$$

Sensible heat between 3 and 4 is

$$
\mathrm{Q}_{\mathrm{c}}=\int_{\mathrm{T}_{\mathrm{a} 1}}^{\mathrm{T}_{\mathrm{g} 2}} \mathrm{C}_{\mathrm{a}}(\mathrm{T}) \mathrm{M}_{\mathrm{a}} \mathrm{dT}+\int_{\mathrm{a} 1}^{\mathrm{T}_{\mathrm{g} 2}} \mathrm{C}_{\mathrm{Lc}}(\mathrm{T}) \mathrm{M}_{\mathrm{a}} \mathrm{X}_{\mathrm{d} 2} \mathrm{dT}+\int_{\mathrm{T}_{\mathrm{a} 1}}^{\mathrm{T}_{\mathrm{g} 2}} \mathrm{C}_{\mathrm{m}}(\mathrm{T}) \mathrm{M}_{\operatorname{madb}} \mathrm{dT} .
$$

Exhausted heat between 4 and 1 is

$$
\begin{aligned}
& \mathrm{Q}_{\mathrm{ad}}=\int_{\mathrm{T}_{\mathrm{a} 2}}^{\mathrm{T}_{\mathrm{a} 1}} \mathrm{C}_{\mathrm{a}}(\mathrm{T}) \mathrm{M}_{\mathrm{a}} \mathrm{dT}+\int_{\mathrm{T}_{\mathrm{a} 2}}^{\mathrm{T}_{\mathrm{a} 1}} \mathrm{C}_{\mathrm{Lc}}(\mathrm{T}) \mathrm{M}_{\mathrm{a}} \mathrm{XdT}+\int_{\mathrm{T}_{\mathrm{a} 2}}^{\mathrm{T}_{\mathrm{a} 1}} \mathrm{C}_{\mathrm{m}}(\mathrm{T}) \mathrm{M}_{\mathrm{madb}} \mathrm{dT}-\int_{\mathrm{T}_{\mathrm{a} 2}}^{\mathrm{T}_{\mathrm{a} 1}} \mathrm{M}_{\mathrm{a}} \mathrm{h}_{\mathrm{a}} \mathrm{d} x \\
& -\int_{\mathrm{T}_{\mathrm{a} 2}}^{\mathrm{T}_{\mathrm{a}}} \mathrm{C}_{\mathrm{pc}}(\mathrm{T})\left(\mathrm{T}-\mathrm{T}_{\mathrm{e}}\right) \mathrm{M}_{\mathrm{a}} \frac{\mathrm{d} x}{\mathrm{dT}} \mathrm{dT} \text {. }
\end{aligned}
$$

The cooling capacity is given as

$$
\mathrm{Q}_{\text {eref }}=\mathrm{M}_{\mathrm{a}} \Delta \mathrm{XL},
$$

where $\mathrm{L}$ is latent heat determined by vaporizing refrigerant

$$
\mathrm{L}_{\mathrm{H} 2 \mathrm{O}}=3171.2-2.4425 \mathrm{~T}(\mathrm{~K}) \text {. }
$$

The modified Dubinin-Astakhov (D-A) equation is [19]

$$
X=X_{0} \exp \left[-K\left(\frac{T_{\text {bed }}}{T_{s}}-1\right)^{n}\right]
$$

where Tbed is adsorbent temperature $(\mathrm{K})$ and Ts corresponds to the refrigerant's adsorbent strength $(\mathrm{K})$. Xo is the highest adsorption power during adsorption $\mathrm{Ts}=\mathrm{Tev}$ and desorption process $\mathrm{Ts}=$ Tcond. $\mathrm{Xo}=0.302 \mathrm{kgkg}^{-1}$, and constants of adsorption $\mathrm{K}$ and $\mathrm{n}$ are set to 4.40 and 2.

Condensation heat is released as

$$
\mathrm{Q}_{\text {cond }}=\mathrm{M}_{\mathrm{a}} \mathrm{L} \Delta \mathrm{x}+\int_{\mathrm{T}_{\mathrm{g} 1}}^{\mathrm{T}_{\mathrm{g} 2}} \mathrm{C}_{\mathrm{pc}} \mathrm{M}_{\mathrm{a}}\left(\mathrm{T}-\mathrm{T}_{\mathrm{c}}\right) \frac{\mathrm{dx}}{\mathrm{dT}} \mathrm{dT} \text {. }
$$

Sensible heat is given as

$$
\mathrm{Q}_{\mathrm{evas}}=\int_{\mathrm{T}_{\mathrm{c}}}^{\mathrm{T}_{\mathrm{e}}} \mathrm{C}_{\mathrm{Lc}}(\mathrm{T}) \mathrm{M}_{\mathrm{a}} \Delta \mathrm{xdT}
$$

$\mathrm{T}_{\mathrm{g} 1}$ in the Clapeyron diagram can be obtained as

$$
\mathrm{T}_{\mathrm{g} 1}=\frac{\mathrm{T}_{\mathrm{c}} \times \mathrm{T}_{\mathrm{a} 2}}{\mathrm{~T}_{\mathrm{e}}}
$$

$\mathrm{T}_{\mathrm{a} 1}$ in the Clapeyron diagram can be calculated as

$$
\mathrm{T}_{\mathrm{a} 1}=\frac{\mathrm{T}_{\mathrm{e}} \times \mathrm{T}_{\mathrm{g} 2}}{\mathrm{~T}_{\mathrm{c}}} .
$$

Desorption heat is given as

$$
\mathrm{H}_{\mathrm{r}}=\frac{\operatorname{RxAxT}}{\mathrm{T}_{\mathrm{c}}}
$$


The COP of adsorption refrigeration can be determined as

$$
\mathrm{COP}_{\mathrm{R}}=\frac{\mathrm{Q}_{\text {eref }}}{\mathrm{Q}_{\mathrm{h}}+\mathrm{Q}_{\mathrm{d}}} .
$$

The COP of an adsorption heat pump can be determined as

$$
\mathrm{COP}_{\mathrm{HP}}=\frac{\mathrm{Q}_{\text {cond }}}{\mathrm{Q}_{\mathrm{h}}+\mathrm{Q}_{\mathrm{d}}} .
$$

SCP and specific heating power (SHP) are the cooling and heating power per cycle time adsorbent mass, defining the system performance.

$$
\begin{aligned}
& \text { SCP }=\frac{Q_{e}}{t_{\text {cycle }} \times M_{a}} \\
& S H P=\frac{Q_{C}}{t_{\text {cycle }} \times M_{a}}
\end{aligned}
$$

\section{Results}

Calculations for exhaust temperatures of $170,210,260,310,360$, and $410{ }^{\circ} \mathrm{C}$ were conducted in this report. The adsorbed bed had a minimal temperature based on seawater temperature. As a function of temperature from the exhaust gas temperature to the maximal adsorbent bed, the water temperature in the cooling system was adsorbed by $\mathrm{Tad}=40{ }^{\circ} \mathrm{C}$ due to a seawater temperature of $32{ }^{\circ} \mathrm{C}$ and condensing temperature by $\mathrm{Tc}=50^{\circ} \mathrm{C}$ due to the heat pump system's warm water temperature; this parameter was taken from evaporation temperature $\mathrm{Te}=4{ }^{\circ} \mathrm{C}$.

Engineering Equation Solver (EES), an overall equation solving application, was used in calculations. The high-precision thermodynamic and transport database is an important aspect of EES.

The adsorbent bed contained $100 \mathrm{~kg}$ of $13 \mathrm{X}$ zeolite grain, and the adsorber and evaporator contained a total of $185 \mathrm{~kg}$ of water. The average weight of the adsorber metal substance was $100 \mathrm{~kg}$. The heat for this pair was $4400 \mathrm{~kJ} / \mathrm{kg}$ for adsorption and desorption.

Figure 4 demonstrates the sum of adsorption versus adsorption. Temperature and friction change the volume of adsorption. As adsorbent temperature increases, the volume of adsorption decreases. Figure 5 shows bed temperatures in the diagram of Clapeyron versus exhaust temperature. $T_{a 1}$ and $T_{g 2}$ temperatures increased, and $T_{a 2}$ and $T_{g 1}$ temperatures rose.

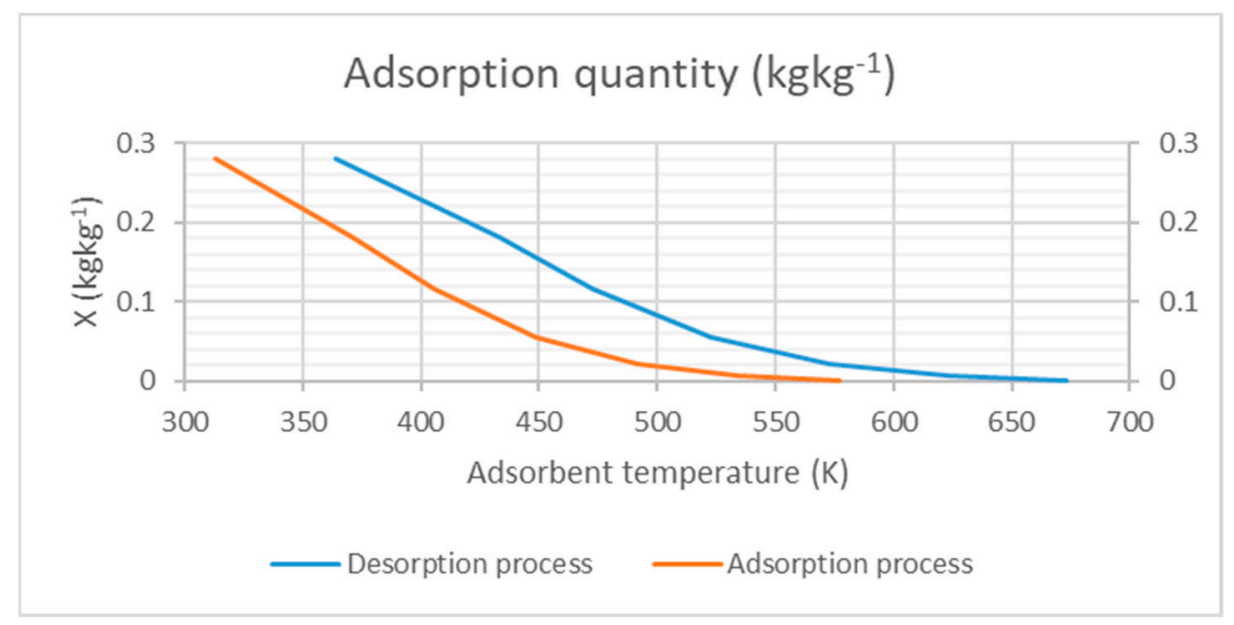

Figure 4. Quantity of adsorption versus adsorbent temperature. 


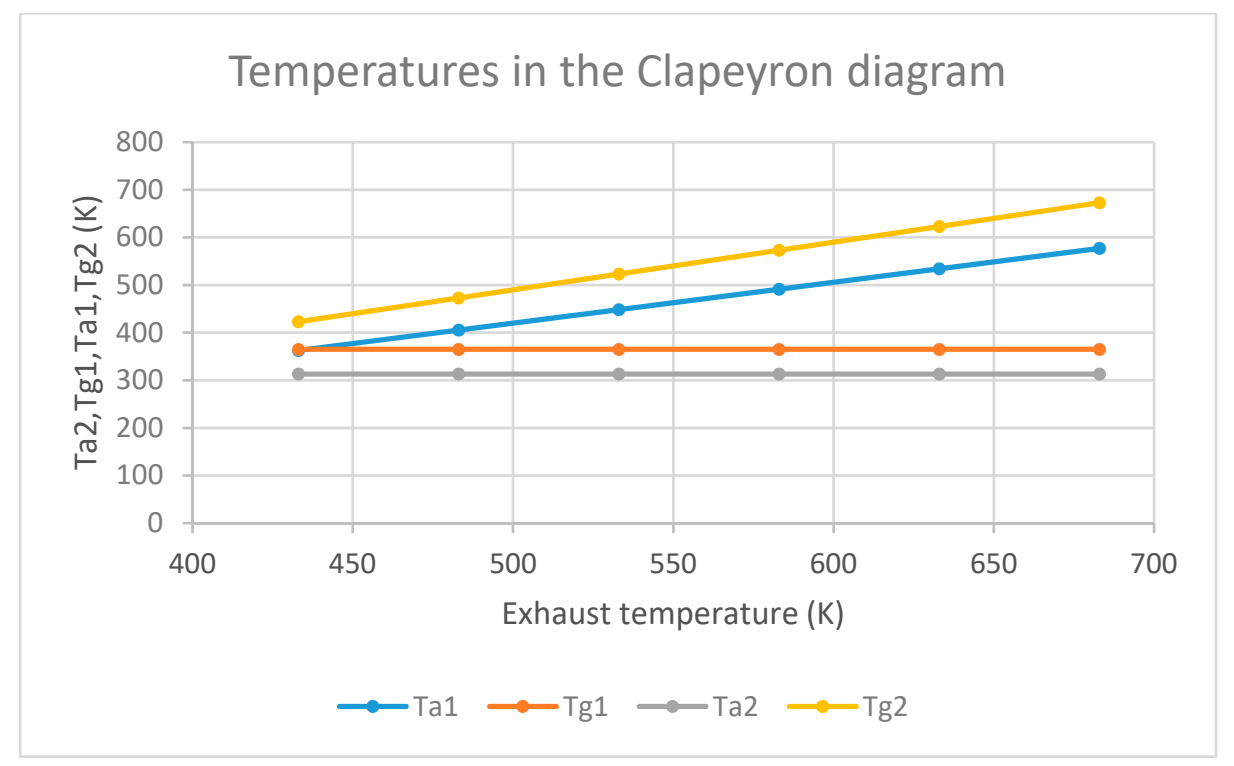

Figure 5. Bed temperature versus exhaust temperature.

Figure 6 displays transmitted thermal energy versus exhaust temperature. Figure 7 shows the heat of evaporation and condensation versus exhaust. The energy transmitted from desorption and adsorption in the bed decreased versus exhaust temperature, while evaporated and condensing heat increased versus exhaust temperature.

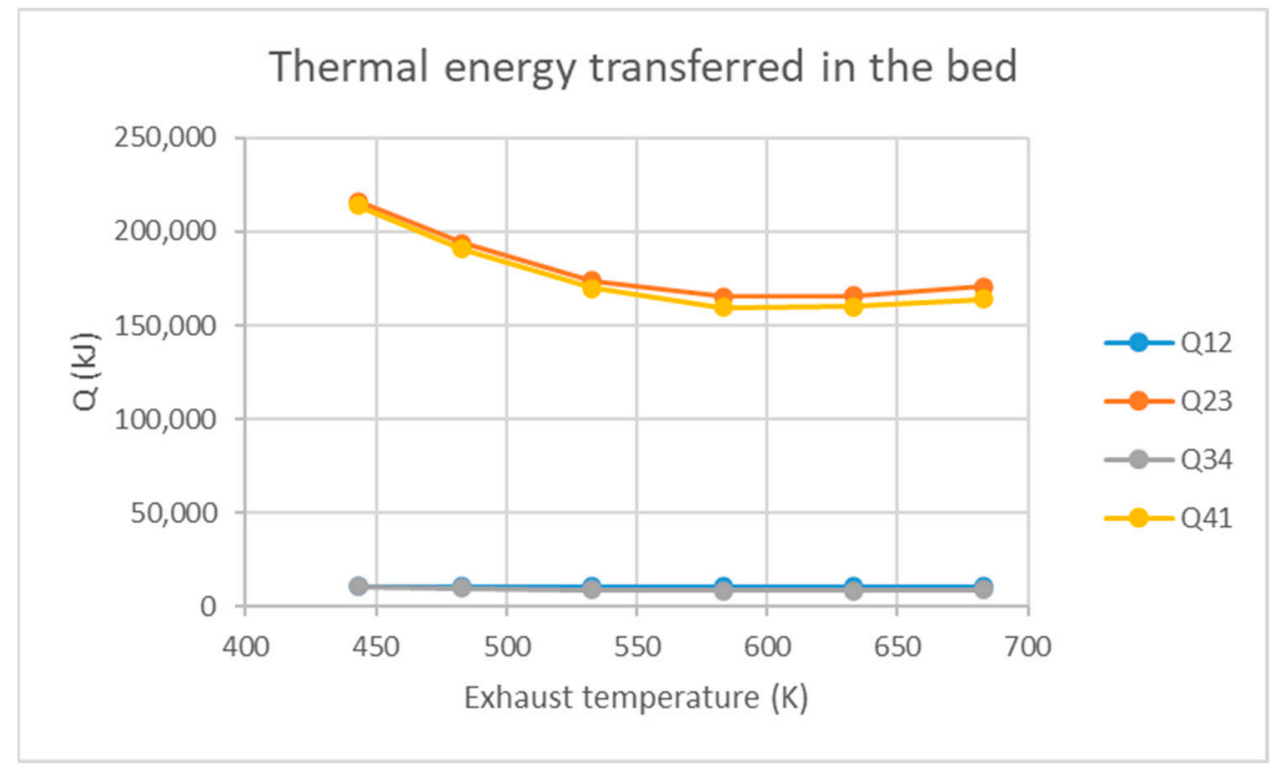

Figure 6. Transmitted thermal energy vs. exhaust temperature.

The COP of the cooling and heating system is seen in Figure 8. The COP of the heating system did not include the exhausted heat into the seawater because it does not require the condenser in the heat pump system. The COP was also smaller than the cooling mode of the heat pump system. Figure 9 displays the SCP and SHP of the device. The adsorption system's COP, SCP, and SHP rose in proportion to exhaust temperature. 


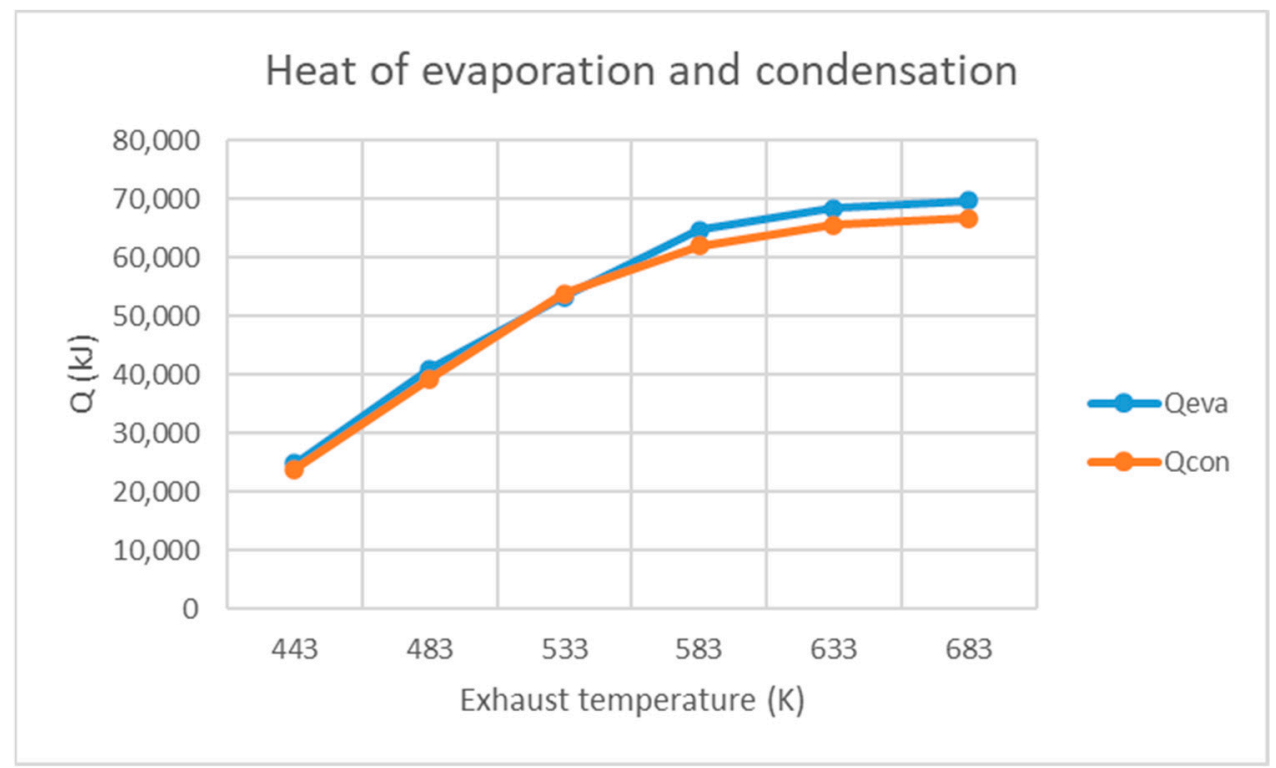

Figure 7. Evaporating and condensing heat vs. exhaust temperature.

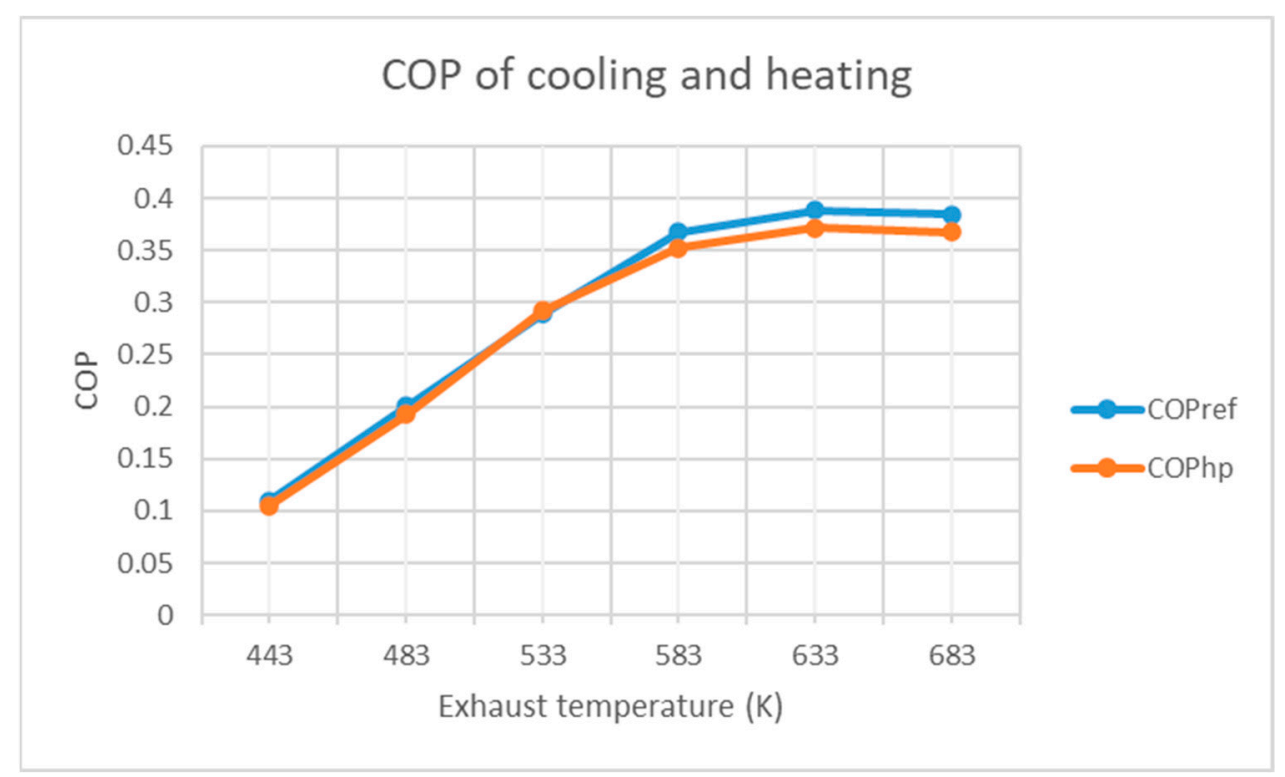

Figure 8. Refrigeration and heat pump coefficient of performance (COP) relative to exhaust temperature.

The experiment findings for the zeolite-water pair for this research and the literature include COP and temperatures for condensation, evaporation, and regeneration, as shown in Table 4. The findings of this analysis are literature-consistent.

Table 4. Coefficient of performance (COP) values researched in the literature.

\begin{tabular}{ccccc}
\hline Reference & $\begin{array}{c}\text { Condensation Temperature } \\
\left({ }^{\circ} \mathbf{C}\right)\end{array}$ & $\begin{array}{c}\text { Evaporation Temperature } \\
\left({ }^{\circ} \mathbf{C}\right)\end{array}$ & $\begin{array}{c}\text { Regeneration Temperature } \\
\left({ }^{\circ} \mathbf{C}\right)\end{array}$ & $\begin{array}{c}\text { COP } \\
\text { This study }\end{array}$ \\
\hline 50 & 40 & 4 & $200-400$ & $0.1-0.38$ \\
Bonarccorsi et al. [20] & 20 & 7 & 150 & 0.46 \\
Tatlier and Şenatalar [21] & 53 & 2 & 123 & 0.3 \\
Ülkü [22] & 52 & 27 & 200 & 0.34 \\
Ülkü [23] & 45 & 10 & $270-450$ & 325 \\
Zhang et al. [24] & 18 & $0.7-16.2$ & $255-296$ & 0.41 \\
Wu et al. [14] & 30 & 10 & 0.4 & 0.38 \\
Zhang et al. [25] & & & & \\
\hline
\end{tabular}




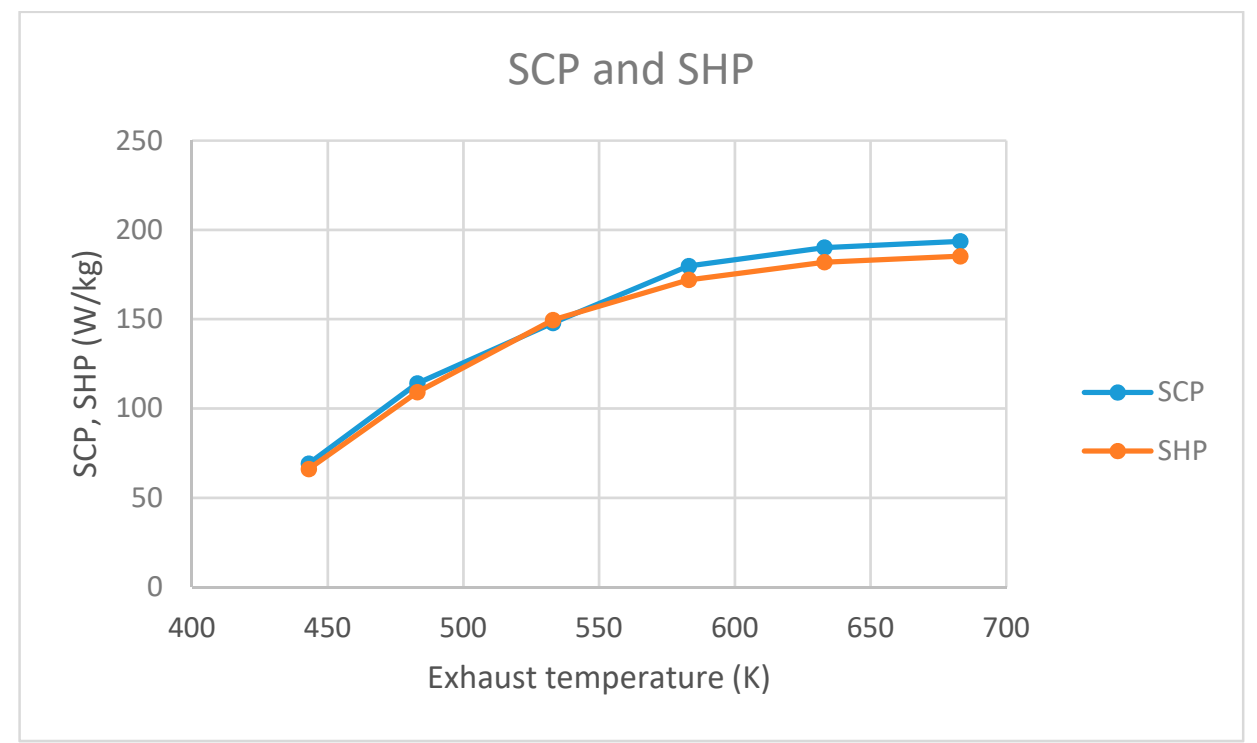

Figure 9. Specific cooling power (SCP) and specific heating power (SHP) versus exhaust temperature.

\section{Discussion}

When exhaust gas temperature varied from 170 to $410{ }^{\circ} \mathrm{C}$, adsorption was equivalent to $40{ }^{\circ} \mathrm{C}$, and cycle time was around $60 \mathrm{~min}$; device values for COP and SCP/SHP were about 0.109 and 0.384 , from 69.13 and $193.58 \mathrm{~W} \mathrm{~kg}^{-1}$ for cooling, and from 0.104 to 0.367 and 66.16 to $185.26 \mathrm{~W} \mathrm{~kg}^{-1}$ for heating based on the temperature of the exhaust gas and regeneration, respectively.

Zeolite-water continuous adsorption refrigeration and heat pump system met $27.64 \%$ and $52.91 \%$, respectively, of cooling and heating load of case ship at the maximum load. Thus, the case system could cool and heat certain spaces.

For the specified conditions, the COP of the heating and cooling system was under 0.4. Although the COP of adsorption cooling and heat pumping was minimal, excess heat intake as a heat supply was free, and thus cost-effective.

The efficient adsorption cooling system benefits from a simple structure and low cost. Adsorption cooling and heat pumps have a life cycle of up to 10-20 years relative to the absorption chill/heat pumps. During its lifespan, zeolite does not need to be replaced. In absorption chillers, however, $\mathrm{Li}-\mathrm{Br}$ replacement is needed within 4-5 years. The refrigeration and heat pump mechanism of the zeolite-water adsorption system is also more convenient for vessels.

The drawbacks of this coupling are that, because of the low working pressure, evaporation temperatures can be below $0^{\circ} \mathrm{C}$, leading to low transfer efficiency [15].

Further experiments should explore the operation of a laboratory-scale waste heatdriven refrigerating device with zeolite-water adsorption.

\section{Conclusions}

A constantly adsorptive cooling and heat pump system with zeolite-water was developed and thermodynamically studied for the surface ship. The concurrent use of adsorption technologies to heat and cool a ship on board was investigated.

The efficiency of the cooling and heat pump adsorption method was compared with that recorded in the literature, and the obtained findings were literature-consistent. Lastly, while zeolite-water is the most convenient working pair for ships in physical adsorption, it can instead be used in the whole ship to cool and heat some places, and/or as a support device for the cooling and heating systems of ships that exist in vapor-compression.

Thus, the designed ship system complies with IMO specifications for shipping and saving fuel to minimize GHG emissions. Besides the EEDI, the infrared and acoustic 
signature of naval ships can be minimized, as the adsorption cooling and heat pump mechanism is free of compressors.

Funding: This research received no external funding.

Acknowledgments: The author would like to thank the editor and the reviewers, and mechanical engineer Azize Ezgi and Mert Ezgi for their helpful comments.

Conflicts of Interest: The author declares no conflict of interest.

\begin{tabular}{|c|c|}
\hline \multicolumn{2}{|c|}{ Abbreviations } \\
\hline C & specific heat, J/kgK \\
\hline CEFS & condenser-evaporator-fan coil-seawater \\
\hline $\mathrm{COP}$ & coefficient of performance \\
\hline $\mathrm{HP}$ & heat pump \\
\hline K & coefficient for D-A equation \\
\hline $\mathrm{L}$ & latent heat, $\mathrm{J} / \mathrm{kg}$ \\
\hline M & mass, $\mathrm{kg}$ \\
\hline $\mathrm{P}$ & pressure, $\mathrm{Pa}$ \\
\hline Q & heat, $\mathrm{kJ}$ \\
\hline$\widehat{\mathrm{R}}$ & universal gas constant, $\mathrm{J} / \mathrm{molK}$ \\
\hline $\mathrm{T}$ & temperature, $\mathrm{K}$ \\
\hline SCP & specific cooling power, $\mathrm{W} / \mathrm{kg}$ \\
\hline SHP & specific heating power, $\mathrm{W} / \mathrm{kg}$ \\
\hline X & adsorption quantity, $\mathrm{kg} / \mathrm{kg}$ \\
\hline Xo & maximal adsorption rate, $\mathrm{kg} / \mathrm{kg}$ \\
\hline \multicolumn{2}{|c|}{ General Subscripts } \\
\hline a & adsorbent \\
\hline $\mathrm{ad}$ & adsorption \\
\hline $\mathrm{adb}$ & adsorber \\
\hline c & cooling \\
\hline cond & condensation \\
\hline d & desorption \\
\hline e & evaporation \\
\hline $\mathrm{h}$ & heating \\
\hline $\mathrm{Lc}$ & liquid refrigerant \\
\hline $\mathrm{m}$ & metal \\
\hline ref & refrigerant \\
\hline s & saturation \\
\hline
\end{tabular}

\section{References}

1. Ezgi, C. Design and thermodynamic analysis of an $\mathrm{H}_{2} \mathrm{O}-\mathrm{LiBr}$ AHP system for naval surface ship application. Int. J. Refrig. 2014, 48, 153-165. [CrossRef]

2. Ezgi, C.; Girgin, I. Design and Thermodynamic Analysis of a Steam Ejector Refrigeration/Heat Pump System for Naval Surface Ship Applications. Entropy 2015, 17, 8152-8173. [CrossRef]

3. Ezgi, C.; Bayrak, S. Experimental Analysis of a Laboratory-Scale Diesel Engine Exhaust Heat-Driven Absorption Refrigeration System as a Model for Naval Surface Ship Applications. J. Ship Prod. Des. 2019, 36, 152-159. [CrossRef]

4. Shu, G.; Liang, Y.; Wei, H.; Tian, H.; Zhao, J.; Liu, L.A. A review of waste heat recovery on two-stroke IC engine aboard ships. Renew. Sustain. Energy Rev. 2013, 19, 385-401. [CrossRef]

5. Xu, X.; Li, Y.; Yang, S.; Chen, G. A review of fishing vessel refrigeration systems driven by exhaust heat from engines. Appl. Energy 2017, 203, 657-676.

6. Qi, X.N.; Zhen, Y.L. A Model of Adsorption Icemaker on a Fishing Boat. Appl. Mech. Mater. 2012, 182-183, 1074-1078. [CrossRef]

7. Wang, S.G.; Wang, R.Z. Recent developments of refrigeration technology in fishing vessels. Renew. Energy 2005, 30, 589-600. [CrossRef]

8. Li, X.H.; Hou, X.H.; Zhang, X.; Yuan, Z.X. A review on development of adsorption cooling-Novel beds and advanced cycles. Energy Convers. Manag. 2015, 94, 221-232. [CrossRef]

9. Demir, H.; Moghtada, M.; Ülkü, S. A review on adsorption heat pump: Problems and solutions. Renew. Sustain. Energy Rev. 2008, 12, 2381-2403. 
10. Wang, L.W.; Wang, R.Z.; Wu, J.Y.; Wang, K.; Wang, S.G. Adsorption ice makers for fishing boats driven by the exhaust heat from diesel engine: Choice of adsorption pair. Energy Convers. Manag. 2004, 45, 2043-2057. [CrossRef]

11. Wang, L.W.; Wang, R.Z.; Wu, J.Y.; Xu, Y.X.; Wang, S.G. Design, simulation and performance of a waste heat driven adsorption ice maker for fishing boat. Energy 2006, 31, 244-259. [CrossRef]

12. Wang, R.Z.; Oliveira, R.G. Adsorption refrigeration-An efficient way to make good use of waste heat and solar energy. Prog. Energy Combust. Sci. 2006, 32, 424-458. [CrossRef]

13. Wang, D.C.; Li, Y.H.; Li, D.; Xia, Y.Z.; Zhang, J.P. A review on adsorption refrigeration technology and adsorption deterioration in physical adsorption systems. Renew. Sustain. Energy Rev. 2010, 14, 344-353. [CrossRef]

14. Wu, W.D.; Hua, Z.; Chuan-lin, M. Performance of a modified zeolite 13X-water adsorptive cooling module powered by exhaust waste heat. Int. J. Therm. Sci. 2011, 50, 2042-2049. [CrossRef]

15. Wang, R.; Liwei, W.; Jingyi, W. Adsorption Refrigeration Technology: Theory and Application; John Wiley and Sons: Singapore, 2014.

16. Ouadha, A.; Youcef, El-G. Integration of an Ammonia-water Absorption Refrigeration System with a Marine Diesel Engine: A Thermodynamic Study. Procedia Comput. Sci. 2013, 19, 754-761.

17. Türk Loydu. Rules for the Classification of Naval Ships. In Ship Operation Installations and Auxiliary Systems; Türk Loydu: Istanbul, Turkey, 2013.

18. Khan, M.S.; Zou, R.; Yu, A. Computational simulation of air-side heat transfer and pressure drop performance in staggered mannered twisted oval tube bundle operating in crossflow. Int. J. Therm. Sci. 2020, in press.

19. Wang, D.C.; Xia, Z.Z.; Wu, J.Y. Design and performance prediction of a novel zeolite-water adsorption air conditioner. Energy Convers. Manag. 2006, 47, 590-610.

20. Bonaccorsi, L.; Freni, A.; Proverbio, E.; Restuccia, G.; Russo, F. Zeolite coated copper foams for heat pumping applications. Microporous Mesoporous Mater. 2006, 91, 7-14. [CrossRef]

21. Tatlier, M.; Şenatalar, A.E. The performance analysis of a solar adsorption heat pump utilizing zeolite coatings on metal supports. Chem. Eng. Commun. 2000, 180, 169-185. [CrossRef]

22. Ülkü, S. Adsorption heat pumps. J. Heat Recovery Syst. 1986, 6, 277-284. [CrossRef]

23. Ülkü, S. Solar Adsorption Heat Pumps, Solar Energy Utilization: Fundamentals and Applications; Martinus Nijkoff Publishers: Leiden, The Netherlands, 1987.

24. Zhang L, Z.; Wang, L. Performance estimation of an adsorption cooling system for automobile waste heat recovery. Appl. Therm. Eng. 1997, 17, 1127-1139. [CrossRef]

25. Zhang L, Z. Design and testing of an automobile waste heat adsorption cooling system. Appl. Therm. Eng. 2000, 20, 103-114. [CrossRef] 